The Work of Art in the Age of Deindustrialization 

POSt $45 \begin{aligned} & \text { Kate Marshall and Loren Glass, Editors } \\ & \text { Post. } 45 \text { Group, Editorial Committee }\end{aligned}$ 


\section{The Work of Art in the Age of Deindustrialization}

Jasper Bernes 
Stanford University Press

Stanford, California

(C) 2017 by the Board of Trustees of the Leland Stanford Junior University. All rights reserved.

This book has been partially underwritten by the Stanford Authors Fund. We are grateful to the Fund for its support of scholarship by first-time authors. For more information, please see www.sup.org/authorsfund.

Part of Chapter 5 was originally published as "Art, Work, Endlessness: Flarf and Conceptual Poetry among the Trolls," in Critical Inquiry @ 2016 by the University of Chicago. Reprinted with permission.

No part of this book may be reproduced or transmitted in any form or by any means, electronic or mechanical, including photocopying and recording, or in any information storage or retrieval system without the prior written permission of Stanford University Press.

Printed in the United States of America on acid-free, archival-quality paper

Library of Congress Cataloging-in-Publication Data

Names: Bernes, Jasper, 1974- author.

Title: The work of art in the age of deindustrialization / Jasper Bernes.

Other titles: Post 45.

Description: Stanford, California : Stanford University Press, 2017. I Series: Post '45 | Includes bibliographical references and index.

Identifiers: LCCN 2016046280 I ISBN 9780804796415 (cloth : alk. paper) I ISBN 9781503602601 (ebook)

Subjects: LCSH: American poetry—2oth century—History and criticism. I Poetry—Social aspects-United States. I Capitalism and literature-United States. I Postmodernism (Literature)—United States. I Work in literature.

Classification: LCC PS325.B47 2017 I DDC 811/.5409-dc23

LC record available at https://lccn.loc.gov/2016046280 